DOI: $10.1515 / \mathrm{rpp}-2017-0050$

PhD in Pedagogical Sciences, Associate Professor, NADIYA TYMKIV Ivano-Frankivsk National Technical University of Oil and Gas, Ukraine Address: 15 Karpatska St., Ivano-Frankivsk, 76018, Ukraine E-mail: nadia_tymkiv@ukr.net

\title{
INTERDISCIPLINARITY IN HIGHER PETROLEUM EDUCATION IN THE CONTEXT OF INTERNATIONAL STANDARDS
}

\begin{abstract}
The article deals with the problem of interdisciplinarity impact on higher petroleum education in Ukraine. Different views on the essence of interdisciplinarity, especially in the context of higher petroleum education, have been presented. It has been indicated that many scholars have studied the essence of interdisciplinarity within higher education systems of different countries and identified that interdisciplinarity encompasses a combination or interrelation of various sciences that are embodied in engineering training process. Interdisciplinarity is considered as one of the effective tools to support enthusiasm of young generation for petroleum engineering; to increase motivation of future petroleum experts; and to enhance the efficiency of collaboration between professionals from different fields. In reality, interdisciplinary approach is very often confused with multidisciplinarity when educators give students knowledge from various disciplines without making the link between them into a coordinated whole. It has been concluded that interdisciplinarity or interdisciplinary approach can be regarded as a natural training context in which boundaries between knowledge systems tend to be erased and a new teaching paradigm is required. It has been revealed that implementation of interdisciplinary approach in engineering programmes necessitates the development of such an educational framework that would provide educators with the relevant methods, tools, and models for design of interdisciplinary engineering curricula regarding specific learning outcomes and ensure support for faculty members to improve their own competence in the interdisciplinary issues.The standards and guidelines of international educational interdisciplinarity of degree programmes in petroleum engineering are analyzed in the article.

Keywords: interdisciplinarity, interdisciplinary approach, petroleum education, interdisciplinary educational technologies, professional competences, the European Higher Education Area, curriculum, the implementation of degree programmes.
\end{abstract}

\section{INTRODUCTION}

The global economy in which petroleum engineers live is in constant change and evolution. The requirements for future petroleum experts today include not only solid technical knowledge but also make them know how to apply that knowledge to real world problems. For these reasons, engineering education must reach beyond the academic world and draw in industry. The real world experiences that future petroleum specialists must have to be effective come from industry and not the more research oriented university environment.

Interdisciplinary approach including globally conditioned interdisciplinarity has been discussed in the context of engineering education since the beginning of the $21^{\text {th }}$ century. This approach contains a number of basic components, namely: structure, process, language, identity, and technologies. The international community has not disputed on the 
significance of interdisciplinary approach for engineers, but the key issue remains how to apply theory for practice in both curricula development and learning process itself.

\section{THE AIM OF THE STUDY}

The purpose of our paper is to analyze the standards and guidelines of international educational interdisciplinarity of degree programmes in petroleum engineering and to reveal such a notion as "interdisciplinarity" which is connected with changes in the system of petroleum training and continuing professional development.

\section{THEORETICAL FRAMEWORK AND RESEARCH METHODS}

The issue of interdisciplinarity has been attracting attention for a long period of time. Having performed theoretical analysis of relevant scientific literature we concluded that scholars all over the world had tried to study the impact ofinterdisciplinarity on future engineers training for petroleum industry at higher technical educational institutions. For instance, L. Brown, A. Chan, G. Codner, J. Fishbein, A. Levine, E. McGrath, A. Lidgett, R. Meeth, C. Nair, A. Patil, A. Russell, A. Repko, M.Tarvainen, N. Walker, T. Williams and others have analyzed the changes occuring within higher education systems in the context of interdisciplinarity. A detailed analysis of the common terminology in this area can be found in studies completed by L. Ackoff, T. Ausburg, J. Borland, V. Budanov, H. Jacobs, $\mathrm{N}$. Nychkalo, O. Shcherbak and others as well as in the proceedings of international conferences held in recent decades, including those held under UNESCO auspices.

To achieve the aim of the study, such research methods as abstraction, specification and systematization of cientific literature.

\section{RESULTS}

The analysis of a great number of Ukrainian and foreign studies concerning the attributes and competencies a graduate petroleum engineer should acquire has revealed importance of interdisciplinary approach among the key factors that ensure competitiveness of oil and gas engineering graduates in labor market.

The notion of interdisciplinarity (multidisciplinarity, crossdisciplinarity, etc.) includes a transdisciplinary perspective as "a way to expand the scientific outlook considering any phenomenon outside the framework of any single scientific discipline" (Patil, 2008). The idea of synthesis and integration of knowledge, that lies in the foundation of this principle probably have more than one millennium already (Chan, 2009).

Traditionally, petroleum engineering education rests on the knowledge of physics, geology, chemistry and mathematics. Petroleum engineering ensures that energy will continue to be a key component to societal functioning and people's everyday lives. Petroleum engineers solve important challenges that contribute to energy security and national prosperity. Petroleum engineers often work on global oil and gas projects in developing areas in developing areas in Asia, Africa, South America and Eastern Europe. However, there are certain limitations in engineering evolution from a purely technical point of view (Tarvainen, 2006).

Professional knowledge is always highly concentrated. With the increasing amount of knowledge, this fact seems to be rather natural. It means that the problems related to highly-specialized knowledge would be solved by standing out them from a wider context, even by separating them from general context. It is obvious that such an approach would never lead to comprehensive solutions which rest on the interdisciplinary approach.

In the 1970s the term interdisciplinarity or interdisciplinary approach was widely applied, however, the issue itself was not frequently addressed in the relevant research literature. The first work that provided definition of interdisciplinary approach was the 
article by R. Meeth who defined "interdisciplinary" as "an attempt to integrate the contributions of several disciplines to a problem, issue, or theme from life" (Meeth, 1978). At about the same time, another American scholar E. McGrath wrote, "the chief purpose of interdisciplinary work is to integrate relevant knowledge around a significant issue" (McGrath, 1978)

The first serious methodological work to reflect discussions of interdisciplinary approach in higher education was "Handbook on the Undergraduate Curriculum" by A. Levine where an entire chapter was devoted to interdisciplinary studies. The scholar defined interdisciplinary approach as "a process of answering a question, solving a problem, or addressing a topic that is too broad or complex to be dealt with adequately by a single discipline or profession" (Levine, 1978). Gradually, educators started the process of moving discussions from definitions to practice. Among the next publications, the works by A. Repko are the most notable. He discussed interdisciplinarity not only within educational context, but also within scientific one (Repko, 2011).

Modern engineers are professionals whose activity directly influences the technological infrastructure of a society. The description of a modern engineer is given in National Guidelines for Engineering Education written and approved by Norwegian National Council for Technological Education (National Council for Technological Education, 2011): "As an engineer you are able to use both your analytical and creative skills to solve socially valuable technological problems. You will have to work innovatively, structurally, and diligently. You have to analyze, generate solutions, assess, determine, execute, and report - be a good entrepreneur. In addition to natural science and technological subjects, your linguistic skills are important, both written and oral, both in Norwegian and in foreign languages. Interacting systems are essential to the modern society, and you must thus be skilled at working independently as well as in teams with engineers from your discipline and from others, professionals from other fields, and in interdisciplinary teams. As an engineer, you will work with people, you will have ethical and environmental responsibilities and you will have a significant impact on society".

Recommendations on European Qualification Framework (EQF) (Learning Opportunities and Qualifications in Europe, 2015) were approved by the European Parliament and the Council of Europe to provide information and facilitate comparison between different qualification systems of European countries. Thus, it aims to develop lifelong learning and facilitate mobility of workforce. The EQF provides a description of all types of qualifications (school compulsory education, higher education, and post-graduate study); three highest levels or cycles of the framework correspond to the Bachelor's degree, the Master's degree, and the Doctoral degree (or its equivalent). The levels of EQF rest on the learning outcomes (knowledge, skills, competence) rather than the programme features (programme duration, type of educational institution, etc.).

Compliance with the labor market demands is the most pressing issue of modern education. Many entrepreneurs complain that the current education systems of most European countries are not providing them with graduates possessing the required skills and competencies. Actually, it was one of the driving forces of the Bologna process. Besides, it also served as an impetus to development and implementation of practice-oriented approach in engineering education - CDIO (Worldwide CDIO Initiative, 2016). It is obvious that in the labor market success of engineering graduates does not only depend on their specific knowledge or skills, but also on the ability to predict the demands for certain new products and processes, work with regard to social and environmental requirements and regulations, 
demonstrate team building and communication skills. Thus, interdisciplinary skills and knowledge play a significant role in future success of a graduate.

Standards and Guidelines for Quality Assurance in the European Higher Education Area do not explicitly mention the necessity of interdisciplinary approach in Bachelor's degree and Master's degree training. However, the guideline to standard "Design and Approval of Programmes" indicates the following: "The education quality is assured due to the facts that programmes: are designed with overall programme objectives that are in line with the institutional strategy and have explicit intended learning outcomes; are subject to a formal institutional approval process; benefit from external expertise and reference points" (Standards and guidelines for quality assurance in the European Higher Education Area, 2015). Thus, those interdisciplinary learning outcomes (competences and skills) that are mentioned in EQF should be in line with the employers' needs and subject to continuous supervision and control. To guarantee that the programmes are delivered in a way that students gain interdisciplinary knowledge and skills, universities should assure themselves of the competence of their teaching staff. Therefore, it is of great importance to recruit lecturers who possess relevant knowledge and skills and are able to ensure qualitative training and give feedback on students' learning achievements. Hence, one of the most complicated tasks is to assure qualitative training of the teachers themselves who will be able to introduce not multidisciplinary, but interdisciplinary approach into education process.

CDIO Standards directly or indirectly cover the issue of interdisciplinarity in engineering education. As it is known, CDIO Initiative is a unique approach to engineering education designated not only to provide students with deep theoretical and practical knowledge within the field of study, but also make them able to design and operate new products, processes, and systems in line with market demands and needs of society. Being an educational framework, CDIO Standards are intended to facilitate developing such engineering programmes that would provide students both with knowledge required to design new products, processes, and systems, and communicative skills. It is obvious that such a goal can only be achieved by implementing interdisciplinary approach.

The criteria of EUR-ACE system developed by EUR-ACE engineering programme accreditation system designed by the European Network for the Accreditation of Engineering Education (ENAEE, 2012) is another framework that provides a set of requirements for the engineering programmes in terms of interdiscipinarity. The introduction to the criteria for accreditation of Professional Bachelor's engineering programmes states: "The curriculum should contain disciplines and interdisciplinary modules that would provide graduates with professional and universal competences including personal and interpersonal skills and expertise in applying engineering systems and processes" (Герасимов, Томилин, 2014). So, it is evident that interdisciplinary approach in Professional Bachelor's degree training is basically aimed at integrating professional and special skills and competences.

The interdisciplinary approach is more widely applied in Master's degree programmes. A graduate of Master's degree programme in petroleum engineering should be able to manage interdisciplinary projects, demonstrate knowledge and understanding of management, communicate clearly to specialist and non-specialist audiences. Engineering activity has significant influence on environment and society, and it always has strong social and environmental impacts. Thus, Master's Degree graduate should have an ability to manage complex technical or professional activities or projects with regard to legal and cultural issues, taking responsibility for decision making. Moreover, curriculum should contain disciplines and interdisciplinary modules that would provide graduates with 
professional and universal competences including personal and interpersonal skills and expertise in applying engineering systems and processes. Practical petroleum engineering skills should be developed upon the completion of interdisciplinary modules and internships, the defense of final graduation papers.

\section{CONCLUSIONS}

Consequently, it can be stated that interdisciplinarity has taken many forms in various educational documents and frameworks. However, in reality interdisciplinarity is often confused with multidisciplinarity which could contribute to developing various graduates' skills and competences, but could hardly integrate knowledge and insights from many disciplines into a coordinated and coherent whole. Recently, Ukrainian technical universities have developed a great number of various education programmes which attractiveness in labor market and quality of education itself increase due to introducing into curriculum such disciplines as English for Specific Purposes, Management, Ecology, etc.

The analysis of various educational initiatives has revealed that implementation of interdisciplinary approach in engineering programmes necessitates the development of such an educational framework that would provide educators with the relevant methods, tools, and models for design of interdisciplinary engineering curricula regarding specific learning outcomes and ensure support for faculty members to improve their own competence in the interdisciplinary issues.

The perspectives for further investigations include the study of an interdisciplinary approach for acquiring social responsibility-related competence and petroleum engineering training for working in interdisciplinary teams and projects.

\section{REFERENCES}

1. Chan, D. (2009). A global engineer for the global community. Policy Engagement, $1(2), 4-9$.

2. European Network for Accreditation of Engineering Education (ENAEE). (2012). The EUR-ACE system. Retrieved from http://www.enaee.eu/eur-ace-system.

3. Gerasimov, S. I., \& Tomilin, A. K. (2014). Kriterii i protcedura professionalnoobshchestvennoi akkreditatcii obrazovatelnykh programm po tekhnicheskim napravleniiam $i$ spetcialnostiam. Tomsk: Tomskii politehnicheskii universitet.

4. Learning Opportunities and Qualifications in Europe. (2015). Descriptors defining levels in the European Qualifications Framework (EQF). Retrieved from http://ec.europa.eu/ ploteus/content/descriptors-page.

5. Levine, A. (1978). Handbook on the undergraduate curriculum. San Francisco: Jossey-Bass.

6. McGrath, E. J. (1978). Interdisciplinary studies: an integration of knowledge and experience. Change: The Magazine of Higher Learning, 10, 6-9.

7. Meeth, R. (1978). Interdisciplinary studies: a matter of definition. Change: The Magazine of Higher Learning, 10 (7), 4-17.

8. National Council for Technological Education (NRT). (2011). National guidelines for engineering education. Retrieved from http://www.uhr.no/ documents/ Nasjonale_retningslinjer_for_ingeni_rutdanning_ENGELSK.pdf.

9. Nychkalo, N. $\bar{H}$. (2011). Innovatsii u rozvytku profesiinoi osvity v umovakh rynku pratsi: dosvid, superechnosti, perspektyvy. Profesiina osvita: pedahohika i psykholohiia, XIII, 91-117. 
10. Patil, A. (2008). Global accreditation for global engineering attributes: A way forward. Retrieved from http://acquire.cqu.edu.au:8080/vital/access/ services/Download/ cqu:4206/ ATTACHMENT01?open=true.

11. Repko, A. (2011). Interdisciplinary Research: Process and theory. Los Angeles: SAGE Publ.

12. Standards and guidelines for quality assurance in the European Higher Education Area. (2015). Retrieved from http://www.enqa.eu/wp-content/uploads/2015/ 11/ESG_2015.pdf.

13. Tarvainen, M. (2006). Engineering education and interdisciplinary studies. Retrieved from http://www.pantaneto. co.uk/ issue22/tarvainen.htm.

14. Worldwide CDIO Initiative. (2016). Retrieved from http://www.cdio.org. 